\title{
Development of Donepezil Hydrochloride Loaded Gellan Gum Based Nasal Mucoadhesive Microspheres by Spray Drying Method
}

\author{
Purushottam Gangane*, Pravin Kawtikwar \\ Sudhakarrao Naik Institute of Pharmacy, Pusad, Yavatmal, Maharashtra, INDIA.
}

\begin{abstract}
Objectives: The aim of present study was the formulation of donepezil hydrochloride loaded polymeric mucoadhesive microspheres for delivery via nasal route to increase the residence time and absorption of drug from the nasal mucosa. Methodologies: The microspheres were formulated by conventional spray drying technique by using gellan gum as a mucoadhesive polymer. A $3^{2}$ full factorial design was utilized with polymer concentration $\left(X_{1}\right)$ and liquid feed flow rate $\left(X_{2}\right)$ as independent variables in formulation of the microspheres and their effect was studied on entrapment efficiency, particle size and drug loading. Results: The results specified that the $X_{1}-X_{2}$ interaction had significant effect on drug loading while $X_{2}$ alone effect on entrapment efficiency and particle size. The optimized microspheres were further evaluated for drug release kinetic study, histological examination, ex vivo permeation study and stability study. Conclusion: It was concluded that the gellan gum containing microspheres of donepezil hydrochloride with mucoadhesive property are suitable for nasal delivery.
\end{abstract}

Key words: Mucoadhesion, Intranasal, Microsphere, Donepezil hydrochloride, Spray drying.

\section{INTRODUCTION}

Donepezil hydrochloride is a centrally acting reversible acetylcholinesterase inhibitor. It is mainly used in the treatment of Alzheimer's disease where it increases cortical acetylcholine. Donepezil hydrochloride showed its therapeutic effect in schizophrenia, mild cognitive impairment and attention deficit disorder. Nasal drug delivery protects the therapeutic drug from gastrointestinal environment, hepatic presystemic metabolism or enzymatic degradation. Therefore, nasal drug delivery has been viewed as the suitable route to deliver the drugs that are susceptible to acidic/basic $\mathrm{pH}$ or enzymatic hydrolysis. ${ }^{1-3}$ In addition, it also provides several advantages over the other conventional route of administration. It is non-invasive, rapid and comfortable mode of drug administration, it also bypasses the blood brain barrier (BBB) and targets the central nervous system (CNS) and thus reduces systemic side effects. ${ }^{4,5}$

Spray drying is a mostly used technique to prepare solid particles, dry powders, granules and microparticles etc. It is a rapid single-step technique of drying with high reproducibility of production of a spherical particle in the micro size range.

The main aim of this study involves developmentof a mucoadhesivemicrosphere formulation of donepezil hydrochloride by spray drying method.

\section{MATERIALS AND METHODS}

\section{Materials}

Donepezil hydrochloride was procured as a gift sample from Cipla, Mumbai. Gellan gum was also obtained from Cipla, Mumbai. All other chemicals, solvents and additives used were of analytical grade.
Submission Date: 08-02-2020; Revision Date: 27-04-2020; Accepted Date: 23-10-2020

DOI: 10.5530/ijper.54.4.187 Correspondence:

Dr. Purushottam S Gangane SN Institute of Pharmacy, Pusad, Yavatmal-445402, Maharashtra, INDIA.

Phone: +919420338543 E-mail: p.gangane@gmail. com

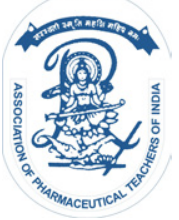

www.ijper.org 
Microspheres preparation by spray drying method

The formulations of donepezil hydrochloride were prepared using gellan gum in three different ratios (Table 1). The feed solutions in definite proportion were formed by dissolving the polymer in distilled water with gentle heating and mixing on a magnetic stirrer to augment the dissolution and the drug was dissolved in this polymeric solution. The microspheres were developed by spraying the feed with a spray dryer (LU222, Labultima, India). The feed solution was atomized under $0.7 \mathrm{~mm}$ nozzle size and inlet air temperature was set at $120^{\circ} \mathrm{C}$. The outlet temperature was ranged between 80 to $90^{\circ} \mathrm{C}$. The feed rate was 3-7 $\mathrm{ml} / \mathrm{min}$, atomizing air flow rate and aspiration rate was kept at $357 \mathrm{~L} / \mathrm{h}$ and $45 \%$ respectively. ${ }^{6,7}$

\section{Experimental Design}

Response Surface Methodology (RSM) was used to recognize the combined effect of two or more factors and also to designate whether or not interaction occurs between the factors and thereby influence the magnitude of the response. The data were interpreted by means of response surface methodology (Design Expert Software Version 11.0.1.0, Stat-Ease, Inc.).

Validation was performed on the basis of results obtained for drug loading, entrapment efficiency and particle size for microspheres of donepezil hydrochloride using Design Expert Software (Version 11.0.1.0, Stat-Ease, Inc.). Overall desirability value is an indicator of the optimum formulation as it is calculated from the individual values which in turn and the same are calculated based on the desired target response of independent variables. ${ }^{8}$

\section{Drug -polymer interactions studies}

A weighed quantity of the donepezil hydrochloride i.e. $1 \mathrm{mg}$ was mixed methodically with potassium bromide (which was previously dried at $40^{\circ}-50^{\circ} \mathrm{C}$ ) and compressed under 10-ton pressure using the hydraulic press to form a pellet. This pellet was then scanned from $4000-400 \mathrm{~cm}^{-1}$ using FTIR spectrophotometer. ${ }^{9-11}$ FTIR absorption spectra of pure drugs, all the polymers used and the combination of drugs and polymers were taken to corroborate the identity for both the drugs and to detect the interaction of the drug with the excipients.

\section{Characterization of mucoadhesive microsphere Production yield}

The production yield of microspheres was calculated from final product weight after drying with respect to the initial total weight of the drug and polymer. The following formula was used to calculate the production yield. ${ }^{12}$

$\%$ Production Yield $=\frac{\text { Practical Mass }(\text { Microspheres) }}{\begin{array}{l}\text { Theoretical Mass } \\ \text { (Polymer+Drug) }\end{array}} \times 100$

\section{Drug loading}

The total quantity of the drug within the microspheres was determined by addition of weighed quantity of microspheres in distilled water and kept overnight. Then solution was filtered through microfilter paper and quantified using U.V Spectrophotometer (UV, Shimadzu, 1800) to determine the drug loading (DL) using the following equation. ${ }^{13}$

$$
\text { Drug Loading } \%=\frac{\begin{array}{c}
\text { wt. of drug loaded in } \\
\text { Microspheres }
\end{array}}{\begin{array}{c}
\text { Total weight of } \\
\text { Microspheres }
\end{array}} \text { X } 100
$$

\section{Particle size analysis}

The particle sizes and morphology were verified in a Motic, B1 series microscope. The sample of microspheres was taken on a microscope slide. A microscopical field was scanned by a video camera. The average particle diameter (particle size) was determined by using the following equation. ${ }^{14}$

Average diameter $=\frac{\sum \mathrm{nd}}{\Sigma \mathrm{n}}$

Where $\mathrm{n}=$ number of microspheres observed, $\mathrm{d}=$ Mean size range.

\section{Zeta potential}

The surface charge of the microspheres was determined with Zetasizer Nano ZS, Malvern instruments. The measurements were carried out in an aqueous solution of $\mathrm{KCl} 0.1 \mathrm{~N}$. Immediately before the determinations microspheres were diluted with $\mathrm{KCl}$ solution. The measured values were corrected to a standard reference

\begin{tabular}{|c|c|c|c|}
\hline \multicolumn{4}{|c|}{ Table 1: Formulation batches (Donepezil HCl: Gellan } \\
Gum). \\
\hline $\begin{array}{c}\text { Batch code } \\
\text { (Drug: Polymer) }\end{array}$ & $\begin{array}{c}\text { Feed rate } \\
\text { (ml/min) }\end{array}$ & $\begin{array}{c}\text { Donepezil } \\
\text { HCl (mg) }\end{array}$ & $\begin{array}{c}\text { Gellan gum } \\
\text { (mg) }\end{array}$ \\
\hline G1 (1:2) & 3 & 200 & 400 \\
\hline G2 (1:2) & 5 & 200 & 400 \\
\hline G3 (1:2) & 7 & 200 & 400 \\
\hline G4 (1:3) & 3 & 200 & 600 \\
\hline G5 (1:3) & 5 & 200 & 600 \\
\hline G6 (1:3) & 7 & 200 & 600 \\
\hline G7 (1:4) & 3 & 200 & 800 \\
\hline G8 (1:4) & 5 & 200 & 800 \\
\hline G9 (1:4) & 7 & 200 & 800 \\
\hline
\end{tabular}


for temperature of $20^{\circ} \mathrm{C}$. The results are the means of triplicate experiments.

\section{Entrapment efficiency}

A weighed quantity of microspheres of donepezil hydrochloride was separately dissolved in distilled water and kept overnight, then vortexed for 1 min to extract the entrapped drug. The solution was then filtered through microfilter paper and quantified using a UV spectrophotometer at $231 \mathrm{~nm} .{ }^{15}$

Entrapment efficiency $\%=\frac{\text { Practical drug content }}{\text { Theoretical drug content }} \times 100$

\section{Swelling Property}

The experiment was performed by dispersing microsphere formulations $(10 \mathrm{mg})$ on Millipore filter $(0.22 \mu \mathrm{m})$ placed on a Franz diffusion cell $(16 \mathrm{ml}$ capacity) filled with buffer solution and kept for 3.5 min to ensure complete equilibrium of swelling. The degree of swelling was determined as per the following equation. ${ }^{16}$

$\alpha=\frac{\mathrm{Ws}_{\mathrm{s}}-\mathrm{Wo}_{\mathrm{o}}}{\mathrm{Wo}_{\mathrm{O}}} \times 100$

Where Wo is the weight of microspheres before swelling, $\alpha$ is a degree of swelling and Ws is the weight of microspheres after swelling.

\section{Scanning Electron Microscopy (SEM)}

The surface morphology of microspheres was identified with the help of scanning electron microscopy (SEM, JSM 6390, JEOL DATUM Ltd., Tokyo, Japan). ${ }^{17}$

\section{In vitro mucoadhesion study}

A freshly cut portion of sheep nasal mucosa $\left(2 \mathrm{~cm}^{2}\right)$ was obtained and cleaned by washing with an isotonic saline solution. Mucosal surface was fixed over polyethylene support at an angle of $45^{\circ}$ with respect to the horizontal plane and measured quantity of microspheres was placed on it. The mucosa was washed with pre-warmed $\left(37^{\circ} \mathrm{C}\right)$ phosphate buffer at $\mathrm{pH} 6.6$ at the rate of $5 \mathrm{ml} /$ min. The amount of drug in collected solution was determined spectrophotometrically after one hour of the administration of microspheres. The quantity of microsphere corresponding to the drug quantity in solution was determined. The disparity between the quantity of microspheres and the applied microspheres present in perfusate was estimated from quantity of adhered microspheres to mucosa. ${ }^{18}$

$$
\text { In vitro mucoadhesion }(\%)=\frac{\begin{array}{c}
\text { Amount of drug in } \\
\text { washout liquid }
\end{array}}{\begin{array}{l}
\text { Actual amount of drug } \\
\text { in applied microspheres }
\end{array}} \times 100
$$

\section{In vitro drug diffusion studies}

An in vitro drug release test of the microspheres was executed using Franz diffusion cells with a dialysis membrane (cut-off Mol. Weight. 12000). The receptor compartment was loaded with phosphate buffer solution of $\mathrm{pH} 6.6$ and microspheres were placed in donor compartment. The donor chamber was adjusted in such a manner that it just touched the diffusion medium in the receptor chamber. The temperature was constantly upholded at $37 \pm 0.5^{\circ} \mathrm{C}$ with the help of a circulating water bath. The microspheres equivalent to $15 \mathrm{mg}$ of drug was dispersed on donor compartment and $3 \mathrm{ml}$ of simulated nasal fluid was added on it. From the receptor compartment, samples were withdrawn periodically and restored with the identical quantity of unsullied pre-warmed buffer solution and assayed using a UV spectrophotometer (UV 1800, Shimadzu, Japan). ${ }^{19}$

\section{Differential scanning colorimetry}

Differential scanning colorimetry (DSC) was performed using Mettler Toledo equipment. This technique determines the thermal change events of given microspheres by measuring the enthalpy, onset of the thermal event, or by determining the melting point of the crystalline material and glass transition temperature of the amorphous material. A weight between 3.5 to 4 $\mathrm{mg}$ of sample was placed into an aluminum pan $(40 \mu \mathrm{l})$ and the pan was sealed using the sealing press apparatus. The samples were heated at a rate of $10^{\circ} \mathrm{C} / \mathrm{min}$ and the scanning was performed between $35-300^{\circ} \mathrm{C} .{ }^{20}$

\section{X-Ray Diffraction study}

The physical states of donepezil hydrochloride microspheres were found out by X-ray diffractometry (Brucker AXS D8 Advance). X-ray diffractograms of pure drug, blank microspheres and drug loaded microspheres were observed. The powder samples were spread on metal sample holders; and glass slide was used to press and smooth the powder surfaces. The diffraction intensity was recorded at 2-theta and the run time was $20 \mathrm{~min}$. The current and voltage generator was set at $35 \mathrm{~mA}$ and $40 \mathrm{kV}$, respectively. ${ }^{21,22}$

\section{Ex vivo permeation study}

Franz diffusion cell was employed to study optimized formulation for drug permeation through the nasal mucosa. The sheep nasal mucosa was fixed between the receptor and donor compartment. In a donor compartment weighed quantities of microspheres were placed and $3 \mathrm{ml}$ of SNF was added to it. Phosphate buffer solution ( $\mathrm{pH}$ 6.6) was filled in receptor compartment and temperature was upholded at 
$37 \pm 0.5^{\circ} \mathrm{C}$. Samples were withdrawn periodically for 4 hr from the receptor compartment and replaced with the same quantity of fresh pre-warmed buffer solution and assayed by means of a UV spectrophotometer (UV 1800, Shimadzu, Japan)..$^{23,24}$

\section{Drug release kinetics}

The drug release data was analyzed with the following mathematical models and interaction of diffusion release mechanism to investigate the drug release mechanism from microspheres.

Zero order kinetics $\mathrm{Q}=\mathrm{Q}_{\mathrm{o}}-\mathrm{K}_{\mathrm{o}} \mathrm{t}$

First order kinetics $\quad \mathrm{Q}=\mathrm{Q}_{\mathrm{o}}\left(1-\mathrm{e}^{-\mathrm{K}}{ }_{1}^{\mathrm{t}}\right)$

Higuchi square root model $\mathrm{Qt}=\mathrm{K}_{\mathrm{H}} \mathrm{t}^{1 / 2}$

Hixson-Crowell cube root model $\sqrt[3]{Q o}-\sqrt[3]{Q t}=\mathrm{K}_{\mathrm{HC}} \mathrm{t}$

Korsmeyer- peppas model Qt/ $\mathrm{Q}_{\infty}=\mathrm{K}_{\mathrm{k}} \mathrm{t}^{\mathrm{n}}$

Where, $\mathrm{Qt}=$ amount of drug release $\mathrm{d}$ at time $\mathrm{t}$.

Qo $=$ initial amount of drug.

And $\mathrm{KH}, \mathrm{K}_{1}, \mathrm{~K}_{\mathrm{HC}}$, $\mathrm{Ko}$ and $\mathrm{K}_{\mathrm{K}}$ are the coefficients of equations. The most appropriate model was selected on the basis of regression values $\left(r^{2}\right)$ and diffusion release exponent (n). Where the value $\mathrm{n}$ is the release exponent characterizes the release mechanism of the drug. The release exponent $n=0.45$ indicates a Fickian diffusion mechanism, $0.45<\mathrm{n}<0.89$ to non- Fickian transport, $n=0.89$ to case II (relaxational) transport and $\mathrm{n}>0.89$ to super case II transport. Drug release kinetics and best fit model for all the selected batches was found out with the help of Microsoft Excel. ${ }^{25-27}$

\section{Stability Studies}

The optimized batch was also subjected to stability studies for six months. The vials filled with microspheres were sealed with rubber caps and kept at moisture conditions $40^{\circ} \mathrm{C}$ and $75 \% \mathrm{RH}$ for duration of 6 months in a stability chamber (CHM-10S, Remi Instruments, Mumbai, India). The samples were tested for particle size $(\mu \mathrm{m})$, swelling $\%$ and mucoadhesion potential $\%$ at the 1-month interval, as per methods mentioned earlier. $^{28}$

\section{Histological study}

The freshly isolated nasal mucosa was taken immediately after sacrificing a healthy sheep from the local slaughter house. The nasal mucosa was sectioned into pieces and washed with a normal saline solution and treated for 8 hr with drug loaded-microspheres. Untreated piece of sheep nasal mucosa was kept as a control. Samples were taken out and washed with sodium chloride solution $(0.9 \%)$ and the tissue was fixed in $10 \%$ buffered formalin and embedded in paraffin wax for $4 \mathrm{hr}$. Paraffin sections
7-5 $\mathrm{mm}$ were cut onto glass slides and stained with hematoxylin and eosin. Sections were inspected by light microscopy to detect any damage during incubation. ${ }^{29}$

\section{Statistical analysis}

All experiments were carried out in a triplicate manner. The obtained data were expressed as mean \pm standard deviation (SD). For statistical calculations, Minitab ${ }^{\circledR}$ ver. 17 was employed. For pharmacological activities, the unpaired Student t-test (two-tailed) was used to determine the difference between control and tested groups.

\section{RESULTS AND DISCUSSION}

\section{Response Surface Analysis}

The quadratic model obtained from the regression analysis was employed to build a 3-D graph in which the responses were signified by curvature surface as a function of independent variables. Three dimensional (3-D) surface plots (Figure 4) were drawn based on the model polynomial functions to assess the change of the response surface. The relationship between the response and independent variables can be expressed visualized from the response surface plots are presented in Figure 5. These plots explain the relationship between the independent variables and dependent variables; i.e. the effects of two factors on the response at one time. The response surface analysis for polymer concentration $\left(\mathrm{X}_{1}\right)$ and feed rate $\left(\mathrm{X}_{2}\right)$ was studied which showed significant results (Figure 6 ). The model $\mathrm{f}$-value of drug loading (213.71), entrapment efficiency (108.65) and particle size (40.22) for polymer concentration $\left(\mathrm{X}_{1}\right)$ and feed rate $\left(\mathrm{X}_{2}\right)$ implies the model is significant. Values of "P" less than 0.0500 indicate model terms are resignificant. The "Pred R-Squared" of 0.997 for drug loading, 0.995 entrapment efficiencies for and 0.990 for particle size is in reasonable agreement with the "Adj R-Squared" of 0.973 for drug loading, 0.999 entrapment efficiencies and 0.998 for particle size. The probability value; i.e. also P-value was found less than 0.0500. This model can be used to develop the design (Table 2).

Final equation in terms of coded factors for particle size, drug loading and entrapment efficiency conveyed that $\mathrm{R}^{2}$ was high pointing out towards the sufficient fitting of the Quadratic Model. As all the three factors showed $(+$ coefficient $)$ it indicated the optimum entrapment efficiency, drug loading and particle size. Based on the obtained results from various evaluation parameters and surface response analysis batch G1 was shown significant results and was observed to be optimized. 


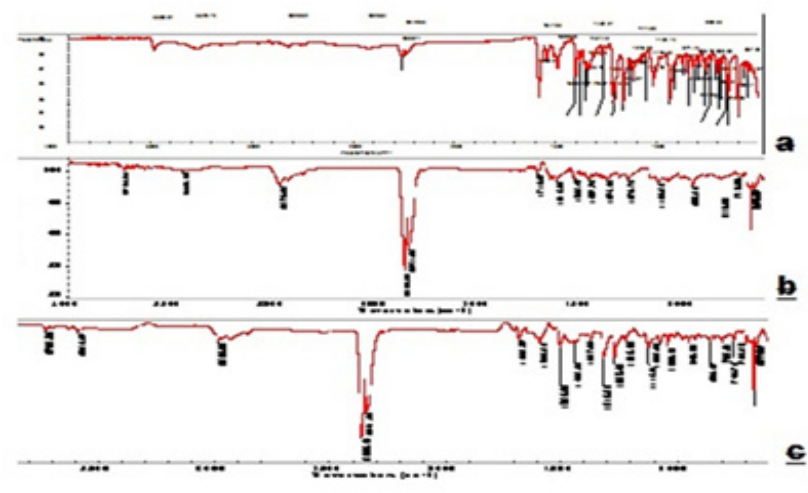

Figure 1: Infrared spectroscopy of a) donepezil hydrochloride b) gellan gum and c) physical mixture.

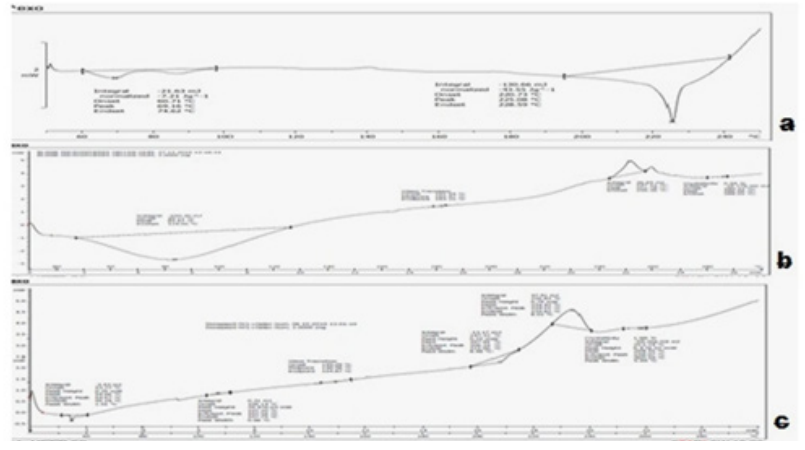

Figure 2: DSC of a) donepezil hydrochloride b) gellan gum and c) drug loaded microspheres.

\begin{tabular}{|c|c|c|c|c|c|c|}
\hline Responses & Source & $\begin{array}{l}\text { Sum of } \\
\text { Squares }\end{array}$ & Df & $\begin{array}{l}\text { Mean } \\
\text { Square }\end{array}$ & F-value & $p$-value \\
\hline \multirow{8}{*}{ Drug loading } & Model & 213.71 & 5 & 42.74 & 267.58 & $<0.0004$ \\
\hline & A-Polymer concentration & 153.19 & 1 & 153.19 & 959.02 & $<0.0001$ \\
\hline & B-Feed Rate & 3.38 & 1 & 3.38 & 21.13 & 0.0194 \\
\hline & $A B$ & 0.6724 & 1 & 0.6724 & 4.21 & 0.1325 \\
\hline & $A^{2}$ & 3.23 & 1 & 3.23 & 20.19 & 0.0206 \\
\hline & $\mathrm{B}^{2}$ & 0.0000 & 1 & 0.0000 & 0.0000 & 1.0000 \\
\hline & Residual & 0.4792 & 3 & 0.1597 & & \\
\hline & Cor Total & 214.19 & 8 & & & \\
\hline \multirow{8}{*}{ Entrapment efficiency } & Model & 108.65 & 5 & 21.73 & 59.43 & $<0.0034$ \\
\hline & A-Polymer concentration & 7.48 & 1 & 7.48 & 20.47 & $<0.0202$ \\
\hline & B-Feed rate & 8.45 & 1 & 8.45 & 23.11 & $<0.0171$ \\
\hline & $A B$ & 1.70 & 1 & 1.70 & 4.66 & $<0.1198$ \\
\hline & $A^{2}$ & 30.94 & 1 & 30.94 & 84.62 & $<0.0027$ \\
\hline & $\mathrm{B}^{2}$ & 1.99 & 1 & 1.99 & 5.45 & $<0.1017$ \\
\hline & Residual & 1.10 & 3 & 0.3657 & & \\
\hline & Cor Total & 109.75 & 8 & & & \\
\hline \multirow{8}{*}{ Particle size } & Model & 40.22 & 5 & 8.04 & 549.90 & $<0.0001$ \\
\hline & A-Polymer concentration & 12.88 & 1 & 12.88 & 880.33 & $<0.0001$ \\
\hline & B-Feed rate & 3.39 & 1 & 3.39 & 231.74 & $<0.0006$ \\
\hline & $A B$ & 0.1640 & 1 & 0.1640 & 11.21 & $<0.0441$ \\
\hline & $A^{2}$ & 0.3990 & 1 & 0.3990 & 27.28 & $<0.0137$ \\
\hline & $\mathrm{B}^{2}$ & 0.4544 & 1 & 0.4544 & 31.06 & $<0.0114$ \\
\hline & Residual & 0.0439 & 3 & 0.0146 & & \\
\hline & Cor Total & 40.27 & 8 & & & \\
\hline
\end{tabular}

\section{Drug -polymer interactions studies}

FTIR spectra of donepezil hydrochloride, gellan gum and their physical mixture were compared. It was observed that there was no functional group inter-conversion when donepezil hydrochloride reacts with the excipients (gellan gum). Donepezil was observed to be compatible with the excipients (Figure 1). The subsequent bands were detected in the FTIR spectrum of physical mixture; i.e., $\mathrm{C}=\mathrm{O}\left(1680 \mathrm{~cm}^{-1}\right), \mathrm{C}-\mathrm{N}\left(1264 \mathrm{~cm}^{-1}\right), \mathrm{C}-\mathrm{O}\left(1036 \mathrm{~cm}^{-1}\right)$, $\mathrm{C}-\mathrm{H}$ bending aromatic $\left(868 \mathrm{~cm}^{-1}\right), \mathrm{C}=\mathrm{C}$ Aromatic $(1588$ $\left.\mathrm{cm}^{-1}\right)$, C-H stretching in $\mathrm{CH}_{3}\left(2920 \mathrm{~cm}^{-1}\right)$.

\section{Characterization of mucoadhesive microspheres Production yield}

The yield of the microspheres varied from $11.8-23.75$ $\%$. Increasing the rate of the feed from 3 to $7 \mathrm{ml} / \mathrm{min}$ 
resulted in decreased production yield. Such tendency was observed with all three concentrations of gellan gum. When increasing the concentrations of polymer from $1: 2$ to $1: 3$ and $1: 4$ at low pump rate of $3 \mathrm{ml} / \mathrm{min}$; an increase in the yield was observed. However, such a tendency was not observed at the feed rate of $5 \mathrm{ml} / \mathrm{min}$ and high $7 \mathrm{ml} / \mathrm{min}$. The highest production yield $(23.75$

$\%$ ) was obtained at low feed rate from $3 \mathrm{ml} / \mathrm{min}$ gellan gum (G1 Batch) (Table 3).

\section{Drug Loading}

The drug loading was observed to be 20.39 - $35.28 \%$. The drug loading goes on lessening as the polymer concentration augments from G1 batch to G9 batch. As the feed rate was increased from $3-7 \mathrm{ml} / \mathrm{min}$, the drug loading decreased (Table 3).

\section{Particle Size Analysis}

The mean particle size of microspheres ranges from $14.36 \mu \mathrm{m}$ to $21.63 \mu \mathrm{m}$, which is ideal for intranasal absorption (Table 3). The lower concentrations of gellan gum (1:2) causes clumping of microspheres, whereas the high concentration of gellan gum (1:3 and 1:4) resulted in formation of disjoined microspheres with a mean particle size $>21.63 \mu \mathrm{m}$. This could be accredited to an augment in the relative viscosity at higher polymer concentration and formation of larger particles. Hence, an optimum gellan gum concentration of $1: 2$ was chosen.

\section{Zeta potential}

Microparticle formulations were characterized also in term of zeta potential because, as well known, it showed positive values in range of 10.4-14.2 which concluded
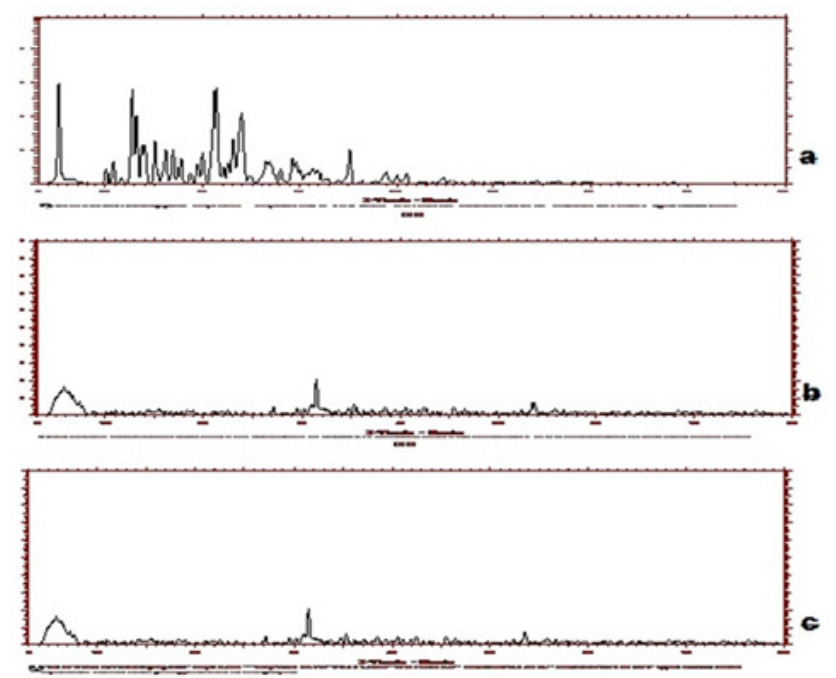

Figure 3: X-Ray diffractogram of a) donepezil hydrochloride b) gellan gum and c) drug loaded microspheres. that electrostatic repulsion between particles with the same electric charge prevents the aggregation of the spheres.

\section{Entrapment Efficiency}

The entrapment efficiency ranged from $75-86.48 \%$. Total drug content of microsphere was estimated by spectrophotometric method. The consequence of polymer concentration on drug entrapment efficiency was studied. No drastic effect was found by increasing the polymer concentration on drug entrapment. In batch G1, the drug entrapment was observed to be highest and having the polymer concentration 1:2 (Table 3).

\section{Swelling property}

The degree of swelling of all the formulations has been shown in (Table 3). Gellan gum has been reported to show good swelling properties. It was shown that with an augment in the quantity of gellan gum, the degree of swelling also increases in the range of $0.42 \pm 0.03$ to $0.66 \pm 0.15$. It is suggested that when the microspheres are in contact with mucus layer, they absorbs the liquid from the mucus layer and swell rapidly, which results in the prolongation of residence time of microspheres in nasal cavity.

\section{In vitro mucoadhesion study}

All formulations were tested for in vitro mucoadhesion studies. It was found that with increasing amount of gellan gum from batch G1 to G9, the mucoadhesive strength of microparticles was increased. The results cleared that the microparticles remain adhered for a prolonged period. The mucoadhesion was in the range of $80.30-94.43 \%$ (Table 3).

\section{ANOVA of Particle Size, Drug Loading and Entrapment Efficiency}

Evaluation and interpretation of research findings are important and the $P$-value serves a valuable purpose in these findings. ANOVA for the dependent variables polymer concentration $\left(\mathrm{X}_{1}\right)$ and feed rate $\left(\mathrm{X}_{2}\right)$ was carried out. The coefficients of $\mathrm{X}_{1}$ and $\mathrm{X}_{2}$ were found
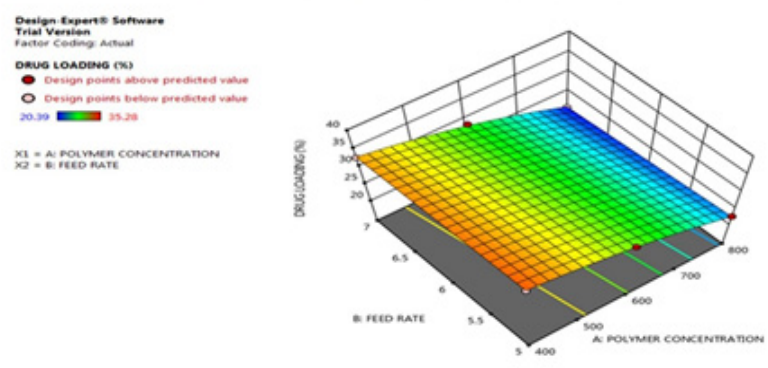

Figure 4: Response 1: (R1) Drug loading 3D graph. 
to be considerable at $p<0.05$, hence it confirmed that both the variables have a noteworthy effect on the selected responses. Overall both the variables caused a significant alteration in the responses.

\section{Validation of results of drug loading, entrapment efficiency and particle size}

Overall desirability value is an indicator of the optimum formulation as it is calculated from the individual values which in turn and the same are calculated based on the desired target response. From Figure 7 for drug loading, entrapment efficiency and particle size; it is clear that the result of drug loading, entrapment efficiency and particle size which was obtained from formulation has optimum concentration of polymers. (Design expert software version 11.0.1.0, Stat-Ease, Inc). The desirability found was 1 and hence it can also be concluded that the acquired results matches with the software prediction and hence the formulation is also validated.

\section{Differential Scanning Calorimetry}

The thermogram of the pure drug showed an endothermic peak at $225.8^{\circ} \mathrm{C}$. The drug loaded microspheres shows a peak at $226.83^{\circ} \mathrm{C}$. Thus it was
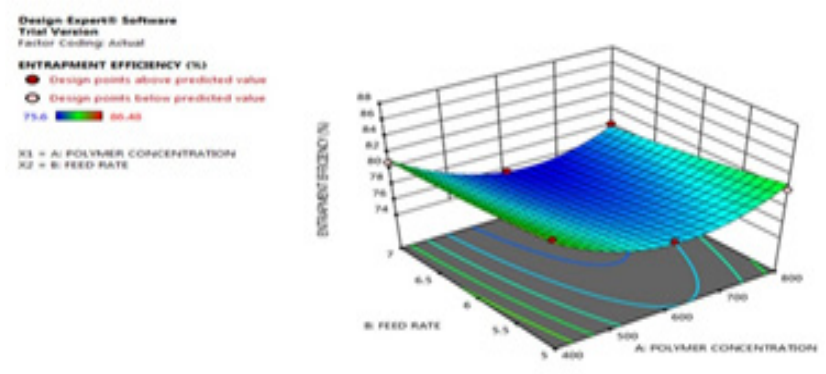

Figure 5: Response 2: (R2) Entrapment efficiency 3D graph. concluded that there was no major interaction between drug and drug loaded microspheres (Figure 2).

\section{X-Ray Diffraction (XRD) Study}

The diffractogram for the pure drug, blank microspheres and drug-loaded microspheres were determined (Figure 3). The diffraction spectrum of pure donepezil hydrochloride showed that the drug is crystalline in nature as demonstrated by numerous distinctive peaks. The prominent drug peak of high intensity at a $2 \theta$ value of 21.251 and peaks of lower intensities at $2 \theta$ values of $12.656,18.594,23.951$ and 35.186 are in agreement with $\mathrm{x}$-ray data found for donepezil hydrochloride. Diffraction pattern of blank gellan gum microspheres show no characteristic peaks indicating that it is amorphous in nature. The XRD profile of the drug loaded microspheres (Figure 3) has shown lower intensity peak demonstrated the amorphous peaks for donepezil $\mathrm{HCl}$ corresponding to $2 \theta$ value of 21.251 and peaks of lower intensities of $2 \theta$ values at 12.656 , 18.594 and 23.951. This data lead to the fact that the drug turned into amorphous form in microspheres but there was no change in lower intensity peaks which means that drug and polymer are compatible.
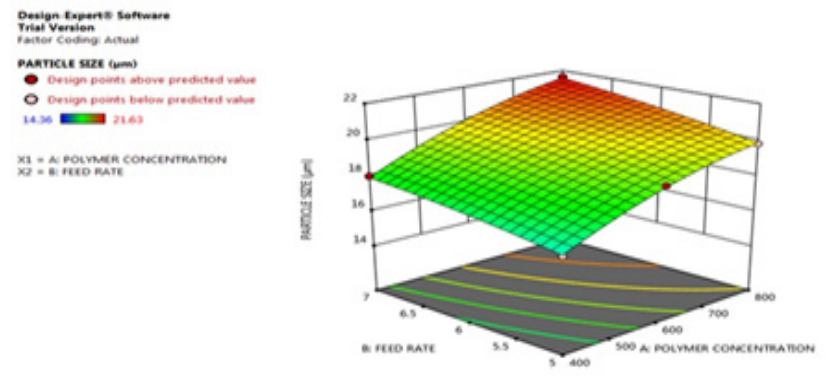

Figure 6: Response 3: (R3) Particle size 3D graph.

\begin{tabular}{|c|c|c|c|c|c|c|c|}
\hline $\begin{array}{l}\text { Sr. } \\
\text { No. }\end{array}$ & $\begin{array}{l}\text { Formulation } \\
\text { Code }\end{array}$ & $\begin{array}{c}\text { Average } \\
\text { Particle Size* } \\
\text { (Mm } \pm \text { SD) }\end{array}$ & $\begin{array}{c}\% \\
\text { Production } \\
\text { Yield * ( }( \pm D)\end{array}$ & $\begin{array}{l}\text { Entrapment } \\
\text { Efficiency } \\
(\%)^{*}( \pm S D)\end{array}$ & 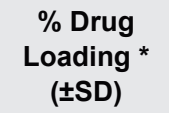 & $\begin{array}{l}\text { Mucoadhesion* } \\
\text { (\%₫SD) }\end{array}$ & $\begin{array}{l}\text { Swelling } \\
\text { Index* } \\
(\% \pm \text { SD) }\end{array}$ \\
\hline 1 & G1 & $14.36 \pm 0.25$ & $23.75 \pm 0.23$ & $86.48 \pm 2.13$ & $35.28 \pm 2.50$ & $80.30 \pm 2.10$ & $0.42 \pm 0.03$ \\
\hline 2 & G2 & $16.57 \pm 0.15$ & $19.83 \pm 0.45$ & $83.24 \pm 1.56$ & $33.85 \pm 1.10$ & $85.85 \pm 0.90$ & $0.46 \pm 0.06$ \\
\hline 3 & G3 & $18.00 \pm 0.51$ & $18.16 \pm 0.39$ & $80.87 \pm 1.29$ & $32.71 \pm 1.50$ & $83.31 \pm 1.10$ & $0.51 \pm 0.10$ \\
\hline 4 & G4 & $16.27 \pm 0.27$ & $22.50 \pm 0.24$ & $82.00 \pm 1.25$ & $30.57 \pm 1.25$ & $89.64 \pm 2.46$ & $0.54 \pm 0.13$ \\
\hline 5 & G5 & $18.79 \pm 0.82$ & $18.50 \pm 0.21$ & $78.24 \pm 1.63$ & $29.57 \pm 0.82$ & $90.21 \pm 0.79$ & $0.62 \pm 0.12$ \\
\hline 6 & G6 & $20.06 \pm 0.22$ & $15.58 \pm 0.12$ & $75.60 \pm 1.72$ & $28.35 \pm 1.22$ & $90.11 \pm 1.69$ & $0.56 \pm 0.09$ \\
\hline 7 & G7 & $17.18 \pm 0.03$ & $22.50 \pm 0.15$ & $86.34 \pm 1.28$ & $24.60 \pm 0.03$ & $92.88 \pm 2.09$ & $0.63 \pm 0.07$ \\
\hline 8 & G8 & $19.82 \pm 0.42$ & $18.40 \pm 0.19$ & $80.23 \pm 1.45$ & $22.53 \pm 1.45$ & $91.54 \pm 1.69$ & $0.54 \pm 0.15$ \\
\hline 9 & G9 & $21.63 \pm 0.40$ & $11.80 \pm 0.31$ & $78.12 \pm 1.40$ & $20.39 \pm 0.45$ & $94.43 \pm 1.83$ & $0.66 \pm 0.15$ \\
\hline
\end{tabular}

*Values expressed as Mean $\pm \mathrm{SD}, n=3$ 


\begin{tabular}{|c|c|c|c|c|}
\hline Formulation & Kinetic Mod & $\left(\mathbf{R}^{2}\right)$ & & \\
\hline \multirow[t]{3}{*}{ G-1 } & Zero order & $\begin{array}{l}\text { First } \\
\text { order }\end{array}$ & Higuchi & $\begin{array}{l}\text { Best fit } \\
\text { model }\end{array}$ \\
\hline & 0.988 & 0.91 & 0.975 & Zero order \\
\hline & $\begin{array}{c}\text { Korsmeyer } \\
\text { Peppas } \\
\text { equation }\end{array}$ & & & \\
\hline \multirow[t]{2}{*}{ G-1 } & $\mathrm{R}^{2}$ & $\begin{array}{c}\mathrm{K} \\
\text { value }\end{array}$ & n'value & Mechanism \\
\hline & 0.973 & 1.765 & 0.737 & $\begin{array}{c}\text { Case II } \\
\text { diffusion }\end{array}$ \\
\hline
\end{tabular}
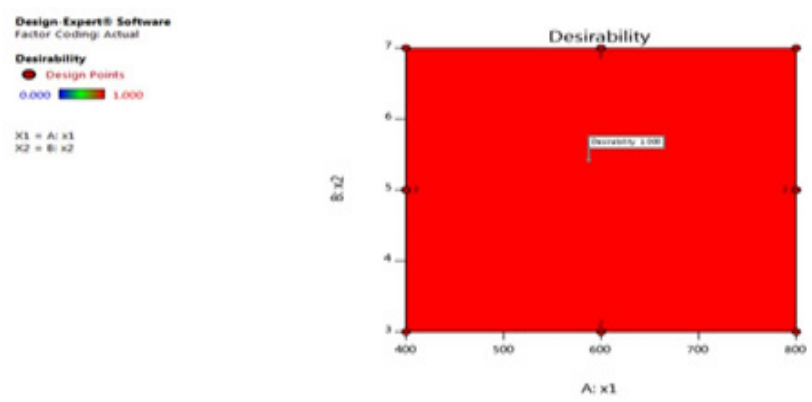

Figure 7: Desirability for all the three responses.

\section{Scanning Electron Microscopy (SEM)}

SEM picture of optimized formulation (G1) is shown in (Figure 8). The microspheres have spherical morphology and smooth surface in shape. The obtained microspheres had no fractures on the surface, which would result in good deposition and cleared slowly from nasal cavity.

\section{In vitro drug diffusion studies}

Franz diffusion cell was employed for in vitro release study of donepezil hydrochloride microspheres with a dialysis membrane (cut-off Mol. Weight. 12000). On the basis of results of entrapment efficiency, particle size and drug loading batch G1 was only taken for in-vitro drug diffusion study. The release profile of donepezil hydrochloride from $\mathrm{G} 1$ batch of microsphere at $\mathrm{pH} 6.6$ of phosphate buffer is shown in (Figure 9). Batch G1 showed zero order drug release and thus considered it as an optimized formulation. The release pattern of the optimized formulation (G1) revealed that drug released from microspheres showing consistent release with zero order, which may be attributed to the lower viscosity of gellan gum.

\section{Drug release kinetics}

The data obtained from drug release were fitted to a variety of kinetic models, to explore the kinetics of

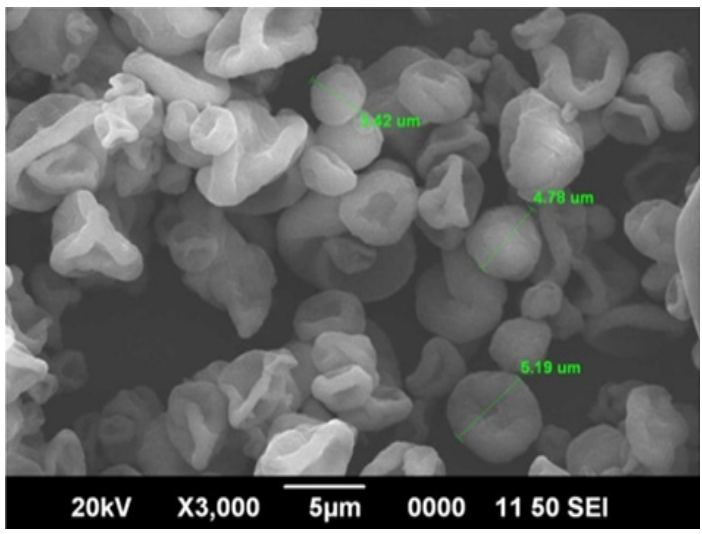

Figure 8: SEM microphotograph of formulation G1.

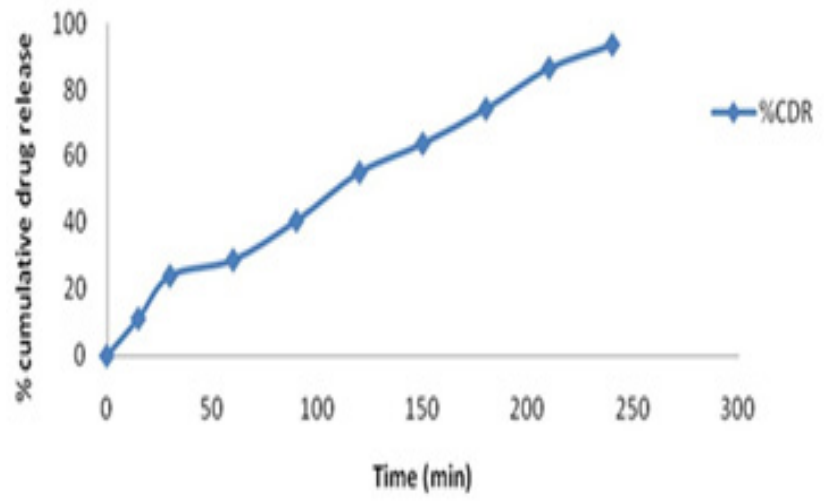

Figure 9: In-vitro drug release study of donepezil hydrochloride loaded microspheres.

drug release. It was observed that the in vitro drug release data was fitted best to zero-order kinetic model, as indicated by highest linearity coefficient $\left(R^{2} 0.988\right)$ when compared to first-order and Higuchi's model. The $\mathrm{n}$-value indicates that the optimized formulation followed the non-Fickian or anomalous diffusion mechanism of drug release, which indicates the linear, time-dependent (zero order) drug release controlled by diffusion of drug through swollen polymer matrix into the external releasing medium (Table 4).

\section{Ex vivo permeation study}

The permeation study was performed in Franz diffusion cells, using the sheep nasal mucosa. The percentages of cumulative permeation of the donepezil hydrochloride incorporated into formulation were plotted against time in (Figure 10). The results obtained revealed more tissue permeation of microsphere. More permeation may be because of the small size of the microsphere. The permeation was found to be $84.92 \%$ at $240 \mathrm{~min}$.

\section{Histological study}

The histological alterations in nasal mucosa caused by formulations have been examined in order to make 


\begin{tabular}{|c|c|c|c|c|}
\hline \multicolumn{5}{|c|}{$\begin{array}{c}\text { Table 5: Stability parameters for donepezil } \\
\text { hydrochloride loaded optimized formulation }\end{array}$} \\
\hline (G1). & $\begin{array}{c}\text { Time } \\
(\text { Days) }\end{array}$ & $\begin{array}{c}\text { Particle Size } \\
(\boldsymbol{\mu m})\end{array}$ & $\begin{array}{c}\text { Swelling } \\
(\%)\end{array}$ & $\begin{array}{c}\text { Mucoadhesion } \\
\text { Potential }^{*}(\%)\end{array}$ \\
\hline 1 & 0 & $14.36 \pm 0.44$ & $0.42 \pm 0.03$ & $80.30 \pm 2.50$ \\
\hline 2 & 30 & $14.34 \pm 0.35$ & $0.42 \pm 0.03$ & $80.10 \pm 0.05$ \\
\hline 3 & 60 & $14.34 \pm 0.86$ & $0.42 \pm 0.03$ & $80.20 \pm 2.01$ \\
\hline 4 & 90 & $14.34 \pm 0.64$ & $0.42 \pm 0.04$ & $80.20 \pm 2.01$ \\
\hline 5 & 180 & $14.34 \pm 0.23$ & $0.42 \pm 0.04$ & $80.20 \pm 2.01$ \\
\hline
\end{tabular}

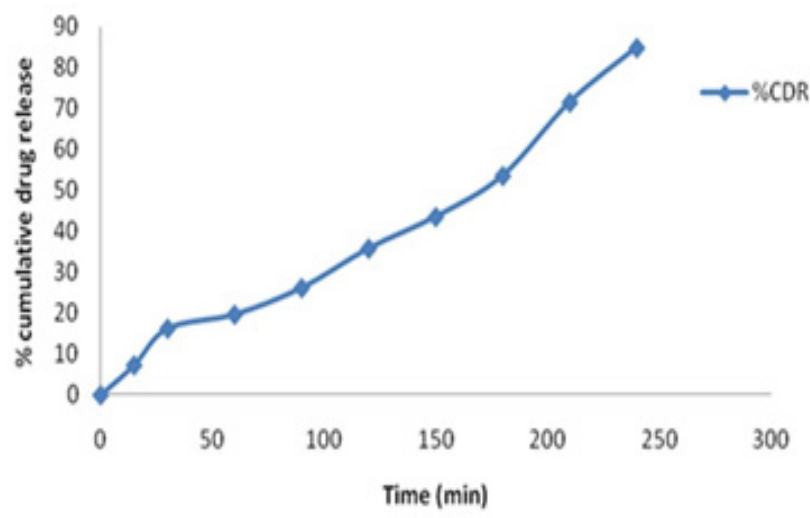

Figure 10: Ex-vivo drug release study of donepezil hydrochloride loaded microspheres (G1). it for practical use. Untreated nasal mucosa and the microspheres treated nasal mucosa has been shown in (Figure $11 \mathrm{a}$ and $\mathrm{b}$ ). The microsphere treated mucosa did not show any deleterious response and adverse effect on the nasal mucosa.

\section{Accelerated Stability Study}

Formulation (G1) showing optimum particle size, swelling property and mucoadhesion were subjected further to the accelerated stability studies at $40^{\circ} \mathrm{C} \pm 2{ }^{\circ} \mathrm{C} / 75 \% \pm 5 \% \mathrm{RH}$ for a period of 6 months. Estimation at each month intervals for three months and last estimation after six months revealed that the changes in particle size, swelling property and mucoadhesion were negligible to conclude that formulation remained stable right through the stability period as given in (Table 5).

\section{CONCLUSION}

From this study it was concluded that spray drying is a suitable method for the formulation of donepezil hydrochloride loaded gellan gum based mucoadhesive microspheres for intra nasal delivery. By selecting and controlling the processing parameters it is feasible to

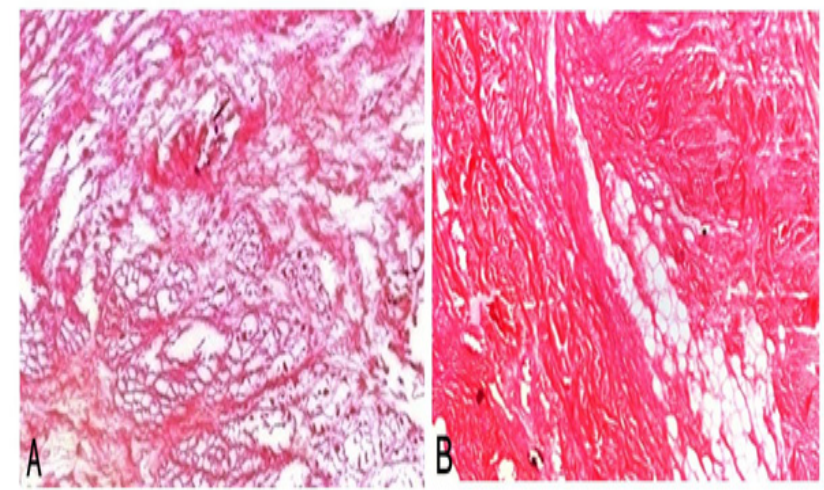

Figure 11: Histology evaluations of sections of untreated sheep nasal mucosa (A) and microspheres treated sheep nasal mucosa.

produce microspheres with desired characteristics such as entrapment efficiency, suitable particle size and drug loading. This study concludes that the microspheres based on gellan gum to be considered as an optimistic nasal delivery system for the administration of donepezil hydrochloride. This interesting formulation deserves further characterization with reference to in vivo studies in the future.

\section{CONFLICT OF INTEREST}

No conflict of interest is declared regarding publication of this manuscript.

\section{ABBREVIATIONS}

SNF: Simulated Nasal Fluid; BBB: Blood brain barrier; CNS: Central nervous system; XRD: X-Ray Diffraction; DSC: Differential Scanning Calorimetry; SEM: Scanning Electron Microscopy.

\section{REFERENCES}

1. Prajapati B, Patel R, Dharamsi A. Intranasal drug delivery system "an overview." Eur J Pharm Med Res. 2017;4:277-83. 
2. Mogal P, Derle D. Use of solid dispersions and inclusion complexation for enhancing oral bioavailability of ziprasidone in treating schizophrenia. J Drug Des Med Chem. 2017;3(3):37-48.

3. Desai S, Vidyasagar G, Shah V, Desai D. Preparation and in vitro characterisation of mucoadhesive microspheres of midazolam: Nose to brain administration. Asian J Pharm Clin Res. 2011;4(1):100-2.

4. Appasaheb PS, Manoha SD, Bhanudas SR. A Review on Intranasal Drug Delivery System. J Adv Pharm Edu Res. 2013;3(4):333-46.

5. Ozsoy Y, Gungor S, Cevher E. Nasal delivery of high molecular weight drugs. Molecules. 2009;14(9):3754-79.

6. Kumar A, Pandey AN, Jain SK. Nasal-nanotechnology: Revolution for efficient therapeutics delivery. Drug Del. 2005;23(3):671-83.

7. Illum L. Is nose-to-brain transport of drugs in man a reality?. J Pharm Pharmacol. 2004;56(1):3-17.

8. Sing C, Pardeshi V, Belgamwar VS. Direct nose to brain drug delivery via integrated nerve pathways bypassing the blood brain barrier: An excellent platform for brain targeting. Exp Opin Drug Del. 2013;10(7):957-72.

9. Ugwoke MI, Agu RU, Verbeke N, Kinget R. Nasal mucoadhesive drug delivery: Background, applications, trends and future perspectives. Adv Drug Del Rev. 2005;57(11):1640-65.

10. Line E, Nicolaas M, Schipper GM, Frans JCV, Merkus WHM. Nasal mucociliary clearance as a factor in nasal drug delivery. Adv Drug Del Rev. 1998;29(1-2):13-38.

11. Ali A, Prajapati SK, Devendra S, Brijesh K, Kausar S. Enhanced bioavailability of drugs via intranasal drug delivery system. Int Res J Pharm. 2012;3:68-74.

12. Illum L. Transport of drugs from the nasal cavity to the central nervous system. Eur J Pharm Sci. 2000;11(1):1-8.

13. Born J. Demonstrating intranasal delivery of neuropeptides to the CSF of humans in nature. Neurosci. 2002;5(6):514-6.

14. Jadhav KR, Gambhire MN, Shaikh IM, Kadam VJ, Sambjahi S. Pisal nasal drug delivery system-factors affecting and applications. Curr Drug Ther. 2007;2(1):27-38.

15. Mahajan HS, Tatiya BV, Nerkar PP. Ondansetron loaded pectin based microspheres for nasal administration: In vitro and in vivo studies. Powder Technol. 2012;221:168-76.

16. Bhowmik D, Kharel R, Jaiswal J, Chiranjib B, Sampath KKP. Innovative approaches for nasal drug delivery system and its challenges and opportunities. Ann Biol Res. 2010;1(1):21-6.
17. Dangre PV, Godbole MD, Ingle PV, Mahapatra DK. Improved Dissolution and Bioavailability of Eprosartan Mesylate Formulated as Solid Dispersions using Conventional Methods. Indian J Pharma Edu Res. 2016;50(3):S209-17.

18. Pardeshi CV, Rajput PV, Tekade AR. Formulation, optimization and evaluation of spray-dried mucoadhesive microspheres as intranasal carriers for Valsartan. J Microencapsul. 2012;29(2):103-14.

19. Nerkar P, Gattani S. Spray-Dried Buccal Mucoadhesive Microparticles of Venlafaxine Based on Cress Seed Mucilage: in vitro, in vivo Evaluation in Rabbits. Drying Technol. 2012;30(9):968-78.

20. Gangane PS, Kadam MM, Mahapatra DK, Mahajan NM, Mahajan UN Design and formulating gliclazide solid dispersion immediate release layer and metformin sustained release layer in bilayer tablet for the effective postprandial management of diabetes mellitus. Int J Pharm Sci Res. 2018;9(9):3743-56.

21. Mahajan NM, Zode GH, Mahapatra DK, Thakre S, Dumore NG, Gangane PS. Formulation development and evaluation of transdermal patch of piroxicam for treating dysmenorrhoea. J Appl Pharm Sci. 2018;8(11):35-41.

22. Khan S, Gangane PS, Mahapatra DK, Mahajan NM. Natural and Synthetic Polymers assisted Development of Lurasidone Hydrochloride Intranasal Mucoadhesive Microspheres. Indian J Pharma Edu Res. 2020;54(1):213-22.

23. Anand U, Feridooni T, Agu RU. Novel mucoadhesive polymers for nasal drug delivery. Recent Adv Novel Drug Carrier Syst. 2012;315-30. DOI 10. $5772 / 52560$.

24. Chaturvedi M, Kumar M, Pathak K. A review on mucoadhesive polymer used in nasal drug delivery system. J Adv Pharm Technol Res. 2011;2(4):215-22.

25. Mahajan NM, Wadhwane P, Mahapatra DK. Rational designing of sustained release matrix formulation of Etodolac employing Hypromellose, Carbomer, Eudragit and Povidone. Int J Pharm Pharm Sci. 2017;9(12):92-7.

26. Patil MD, Mahapatra DK, Dangre PV. Formulation and in-vitro evaluation of once-daily sustained release matrix tablet of nifedipine using rate retardant polymers. Inventi Impact Pharm Tech. 2016;2016(4):190-6.

27. Mahajan NM, Pardeshi A, Mahapatra DK, Darode A, Dumore NG. Hypromellose and Carbomer induce bioadhesion of Acyclovir tablet to vaginal mucosa. Indo American J Pharm Res. 2017;7(12):1108-18.

28. Umaredkar A, Dangre PV, Mahapatra DK, Dhabarde DM. Fabrication of chitosan-alginate polyelectrolyte complexed hydrogel for controlled release of cilnidipine: A statistical design approach. Mater Technol. 2018;1:1-11.

29. Dhawale P, Mahajan NM, Mahapatra DK, Mahajan UN, Gangane PS. HPMC K15M and Carbopol 940 mediated fabrication of ondansetron hydrochloride intranasal mucoadhesive microspheres. J Appl Pharm Sci. 2018;8(8):75-83.3.

\section{PICTORIAL ABSTRACT}

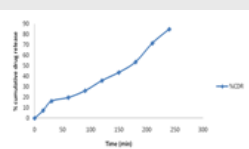

IN VITRO DIFFUSION STUDY
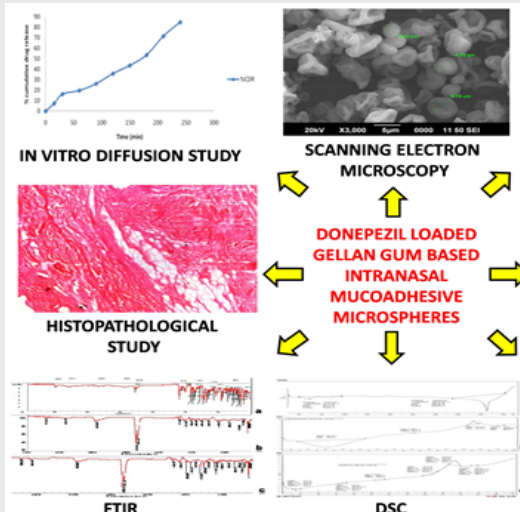

DONEPEZIL LOADED GELLAN GUM BASED INTRANASAL MICROSPHERES

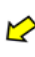

\&
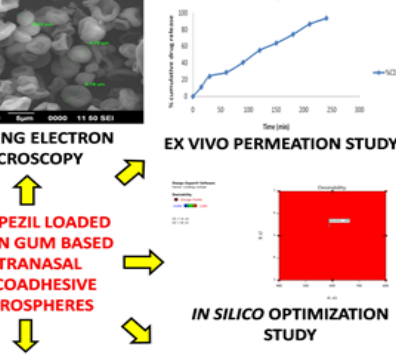

EX VIVO PERMEATION STUDY

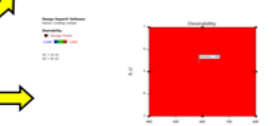

IN SILICO OPTIMIZATION STUDY

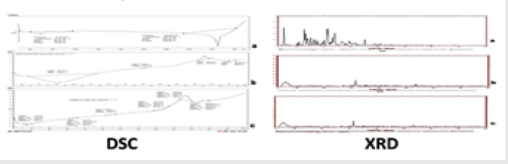

\section{SUMMARY}

- Formulation of donepezil hydrochloride loaded polymeric mucoadhesive microspheres for delivery via nasal route to enhance the residence time and absorption of drug through the nasal mucosa.

- $3^{2}$ full factorial design was employed with polymer concentration $\left(\mathrm{X}_{1}\right)$ and liquid feed flow rate $\left(X_{2}\right)$ as independent variables in formulating the microspheres and their effect was studied on entrapment efficiency, particle size and drug loading.

- The optimal microspheres were evaluated for drug release kinetic study, ex vivo permeation study, histological examination and stability study. 


\section{About Authors}

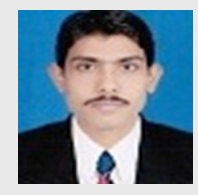

Purushottam Shridhar Gangane is working as an Associate Professor, Department of Pharmaceutics at Dadasaheb Balpande College of Pharmacy, Nagpur. He has more than 14 years of teaching and research experience. He has guided 18 post-graduate students under his supervision. He has published $15+$ research publications in the journals of repute and also authored several book chapters for international press. He has presented several papers in national as well as international conferences and received numerous awards. He is a life member of APTI and also a member of CRS-India Chapter. His areas of research expertise include nasal drug delivery and multiparticulate drug delivery system.

Pravin Kawtikwar is currently working as the Principal and Professor in Pharmaceutics at S. N. Institute of Pharmacy, Pusad, Dist. Yavatmal, Maharashtra. He has more than 25 years of teaching and research experience. He has guided 56 post-graduate students and guided 5 research scholars under his supervision. He has published $50+$ research papers in the journals of repute and holds an Indian Patent on Pelletization Technique. He has presented several papers in national as well as international conferences and received numerous awards. He is a life member of APTI, IPA, ISTE, IHPA, etc. His areas of research expertise include industrial pelletization technology and modern non-conventional drug delivery systems.

Cite this article: Gangane P, Kawtikwar P. Development of Donepezil Hydrochloride Loaded Gellan Gum Based Nasal Mucoadhesive Microspheres by Spray Drying Method. Indian J of Pharmaceutical Education and Research. 2020;54(4):935-45. 